\title{
National Security Assessment Method Based on Fuzzy Sets Theory
}

\author{
A. B. Kachynskyi ${ }^{1}$ \\ ${ }^{1}$ National Technical University of Ukraine «Igor Sikorsky Kyiv Polytechnic Institute», \\ Institute of Physics and Technology
}

\begin{abstract}
National security is a complex multilevel system whose state of security depends on many uncertainties, so developing a method of assessing the level of national security, based on a mathematical modeling using fuzzy logic that makes use of both quantitative and qualitative information with the conclusion in the form of linguistic characteristics of the phenomenon allows simultaneous use of different types of information: deterministic, statistical and linguistic, which is difficult to implement using other methods. As a result, linguistic assessment of the state security can be formulated as a statement «high level-low». Described approach can also be useful for monitoring the dangerous processes taking place in the field of national security.
\end{abstract}

Keywords: National security, fuzzy sets, index approach, indicator approach, integral indicators approach, critical tresholds approach, security of the state

\section{Formulation of the problem}

Analysis of the literary sources. At the moment, the term "security" is understood as the state of society and state when for every person living in the country, his rights and civil freedoms are protected, as well as the reliability of existence and sustainable development of the state, protection of its basic material and spiritual values, the constitutional system and state sovereignty, independence and territorial integrity from internal and external threats.

In the context of the ongoing "hybrid war", the weight of not only the Armed Forces, but also of transforming the role of all its components, where cybernetic security plays a key role, is substantially increasing. In order to effectively confront an aggressor and to convincingly demonstrate to the world our subjectivity, we need to clearly understand our role and place in the global dimension, which requires the development of mathematical models for assessing the level of national security.

At the moment, it is possible to distinguish the following approaches to assessing the level of national security: the index approach, the indicator approach, the approach based on the assessment of critical thresholds, the approach is based on the assessment of the integral indicator, an approach that involves determining the state of the administrative-legal regime.

The index approach is based on the fact that many researchers are now trying to determine the state of national security through various indexes, calculated by reputable international organizations or rating agencies. First of all, it concerns the global index of peace, the country's failure index, the index of political risk, the index of corruption perception, etc. [1, 2]. However, with the help of these indices, one can not approach the analysis of national security from the common methodological positions. With their help, it is impossible to identify and develop generalized assessments of the hazardous states of systems, to develop appropriate security mechanisms in the form of direct influence on the critical parameters of the system, while preventing the emergence of new threats. [3].

The indicator approach to assessing the level of national security is considered in $[4,3,5]$. The level of national security is determined by the results of monitoring and comparison of changes in certain indicators of the state of life with indicators-indicators. At the moment, the practical implementation of this approach is problematic: it involves, in the first place, a high culture of scientific thinking, which begins with a clear idea of the concept-categorical apparatus. In Ukraine, with regard to such categories as parameter, indicator, criterion, etc., many closely related terms are used. In addition, for this approach, many questions arise about the methodological foundations for defining the set of indicators.

The theoretical basis of the approach based on the assessment of critical thresholds for determining the level of national security is the concept of "homeostasis" - a specific, in fact, biological phenomenon, which outlines the constancy of a certain set of characteristics, under which maintenance of the vital system is maintained. According to many researchers $[3,6,7,8]$ the mechanism of homeostasis determines the conditions for the safe existence of man, society, ecosystems, as well as the state as a whole. After all, it is the understanding of security as the protection of the vital interests of man, society, state, as well as the environment from various threats, to determine the permissible values and the values of their negative impacts on security objects that would not lead to death or degradation. However, the practical definition of these boundaries, that is, the critical values of the parameters of the system, is closely related to the concept of dynamic stability - the preser- 
vation of the invariance of some essential characteristics of complex systems, regardless of external influences, which does not always have a theoretical solution.

The approach using the assesement of the integral indicator is based on the integration of indicators that determine the level of national security $[3,9]$. This approach draws attention to the fact that it is complex and takes into account various aspects of national security: political, economic, socio-economic, ecological, informational, etc. However, this indicator can not be used to assess the state of national security, because it does not take into account the basic laws of the emergence of threats in systems of different functional purposes, structural relations between individuals, society, and the state, achieving a real practical effect.

An approach based on determining the state of the administrative-legal regime involves a certain combination of administrative and legal means of regulation, which are manifested in a centralized manner, an imperative method of legal influence and legal inequality of subjects of legal relationships [10, 11, 3]. When using this approach, much attention is paid to the interpretation of the notion of "legal regime", under which the majority of researchers and lawyers now understand the procedure established by law for the use of the object, the permissible limits and methods for disposing of it. On the one hand, the advantage of this method is that the assessment of the level of national security is identified with the state defined by the administrative-legal regime at the given time. On the other hand, all his shortcomings have clearly manifested themselves at the time of an immediate, adequate response to Russia's military aggression - discussions such as "Ukraine needs a legal regime of ATO or a military state?" The reason is that domestic legislation was created on the basis of old ideas about the classic war, and does not take into account the realities of the hybrid aggression faced by Ukraine.

It is obvious that the practical implementation of all these approaches is controversial. In each case, it is a question of a set of indicators of the state's vital activity, the composition of which is determined ambiguously. In some cases, their number is quite large, however, not all aspects of the state's vital functions, which characterize the degree of its security. Among the drawbacks include the lack of specific methods for evaluating indicators and critical or threshold values. Quite often the information about them is controversial and so on.

The study is to develop a method of assessing the level of national security, based on a mathematical model of fuzzy logic that makes use of both quantitative and qualitative information with the conclusion in the form of linguistic characteristics of the phenomenon.

\section{Presentation of the main material}

The subject of the study of fuzzy logic is the study of judgments under uncertainty. The most important application of the theory of fuzzy sets is the knowledge of experts. This knowledge can be expressed using linguistic variables described by fuzzy sets. This approach has proven itself well in solving complex problems of financial and economic security $[12,13,2]$.

\section{Step 1: Linguistic variable}

National security is a complex multilevel system whose state of security depends on many uncertainties, which makes it necessary to use the theory of fuzzy sets. In our opinion, this approach allows adequately to take into account all uncertainties: the assessment of the level of national security is described as a linguistic variable with its term-sets of values. The connection between the quantitative values of some factor and its qualitative linguistic description is given by the function of the membership of this factor in the fuzzy set $[14,15,16]$.

Consider the linguistic variable $\mathrm{E}=$ «national security of the state». The set of national security values consists of seven fuzzy subsets corresponding to Miller's base scale [17]: $E_{1}$ is extremely low, $E_{2}$ is very low, $E_{3}$ is low, $E_{4}$ is average, $E_{5}$ is high, $E_{6}$ is very high, $E_{7}$ is extremely high.

\section{Step 2: The meaning of the linguistic variable}

The universal set $\mathrm{G}=$ «state of the state security», which corresponds to the linguistic variable $\mathrm{E}$, is a segment $[0,1]$. The set of values of the linguistic variable $G$ is a term set $G=G_{1}, G_{2}, G_{3}, G_{4}, G_{5}, G_{6}, G_{7}$, where

- $G_{7}=$ extremely low;

- $G_{6}=$ very low;

- $G_{5}=$ low;

- $G_{4}=$ average;

- $G_{3}=$ high;

- $G_{2}=$ very high;

- $G_{1}=$ extremely high.

The carrier of the set $\mathrm{G}$ - state of state protection $\mathrm{g}$ - takes value on the segment $[0,1]$. In the future, we shall consider these fuzzy subsets as trapezoidal fuzzy numbers (Fig. 1).

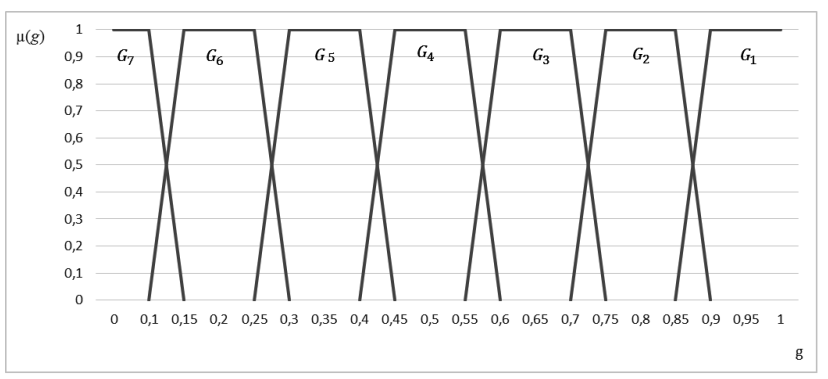

Fig. 1. The function of the membership of the subsets of the term-set $g$.

The upper base of the trapezium corresponds to the complete conviction of the expert in the faithfulness of the selected classification, and the bottom one - to the conviction that no other values from the interval $[0,1]$ fall into this fuzzy set. 


\section{Step 3: The membership function table for each term.}

Four key numbers are required for a keystroke function $\left(a_{1}, a_{2}, a_{3}, a_{4}\right)[18]$

$$
\mu(x)= \begin{cases}0 & \text { if } x<a_{1} \\ \frac{x-a_{1}}{a_{2}-a_{1}} & \text { if } a_{1} \leq x<a_{2} \\ 1 & \text { if } a_{2} \leq x \leq a_{3} \\ \frac{x-a_{4}}{a_{3}-a_{4}} & \text { if } a_{3} \leq x<a_{4} \\ 0 & \text { if } x>a_{4}\end{cases}
$$

\begin{tabular}{|c|c|c|}
\hline Term $\mathbf{G}_{\mathrm{k}}$ & \multicolumn{2}{|c|}{ The membership function of fuzzy set $G_{k}$} \\
\hline$G_{7} \in[0 ; 0,15]$ & $\mu_{7}=\left\{\begin{array}{c}1 \\
20(0,15-g)\end{array}\right.$ & $\begin{array}{l}0 \leq g \leq 0,1 \\
0,1<g \leq 0,15\end{array}$ \\
\hline$G_{6} \in[0,1 ; 0,3]$ & $\mu_{6}=\left\{\begin{array}{c}1-20(0,15-g) \\
1, \\
20(0,3-g)\end{array}\right.$ & $\begin{array}{l}0,1<g \leq 0,15 \\
0,15<g \leq 0,25 \\
0,25<g \leq 0,3\end{array}$ \\
\hline$G_{5} \in[0,25 ; 0,45]$ & $\mu_{5}=\left\{\begin{array}{c}1-20(0,3-g) \\
1 \\
20(0,45-g)\end{array}\right.$ & $\begin{array}{l}0,25<g \leq 0,3 \\
0,3<g \leq 0,4 \\
0,4<g \leq 0,45\end{array}$ \\
\hline$G_{4} \in[0,4 ; 0,6]$ & $\mu_{4}=\left\{\begin{array}{c}1-20(0,45-g) \\
1, \\
20(0,6-g),\end{array}\right.$ & $\begin{array}{l}0,4<g \leq 0,45 \\
0,45<g \leq 0,55 \\
0,55<g \leq 0,6\end{array}$ \\
\hline$G_{3} \in[0,55 ; 0,75]$ & $=\left\{\begin{array}{c}1-20(0,6-g), \\
1, \\
20(0,75-g),\end{array}\right.$ & $\begin{array}{l}0,55<g \leq 0,6 \\
0,6<g \leq 0,7 \\
0,7<g \leq 0,75\end{array}$ \\
\hline$G_{2} \in[0,7 ; 0,9]$ & $\mu_{2}=\left\{\begin{array}{c}1-20(0,75-g), \\
1, \\
20(0,9-g),\end{array}\right.$ & $\begin{array}{l}0,7<g \leq 0,75 \\
0,75<g \leq 0,85 \\
0,85<g \leq 0,9\end{array}$ \\
\hline$G_{1} \in[0,85 ; 1]$ & $\mu_{1}=\left\{\begin{array}{c}1-20(0,9-g) \\
1,\end{array}\right.$ & $\begin{array}{l}0,85 \leq g \leq 0,9 \\
0,9<g \leq 1\end{array}$ \\
\hline
\end{tabular}

Fig. 2. The membership function of the subsets of the term-set $g$.

The value of the membership function is considered as a measure of the truth of the term $G_{i}$.

\section{Step 4: National Security Indicators System.}

The state of national security can be characterized by many indicators. However, real and potential threats, first of all, for the following areas: military, internal political, economic, social and humanitarian, scientific and technological, environmental, as well as Euro-Atlantic orientation of Ukraine's foreign policy, should be taken into account when defining them. The criteria for their determination should be: the level of the object of protection of national security - the main objects of state protection; degree of significance - macroeconomic indicators; the direction of the challenges and threats external and internal; period of threats - medium and long-term; the nature of the risks - strategic. An expert for the constructive description of the linguistic variable must be determined with the quantitative indicators of the system of indicators of national security, designed in a special way and those that take values from zero to one. In our opinion, such a system of indicators of national security $X=X_{1}, X_{2}, X_{3}, X_{4}, X_{5}, X_{6}, X_{7}, X_{8}$ should be:

- $X_{1}$ - depopulation rate;

- $X_{2}$ - coefficient of financing of needs of the national defense of the state;

- $X_{3}$ - the level of economy "shadowing";

- $X_{4}$ - the decile coefficient;
- $X_{5}$ - ratio of total public debt to GDP,

- $X_{6}$ - the cost of science and education;

- $X_{7}$ - environmental costs;

- $X_{8}$ - crime.

The above indicators are determined by accurate calculations (depopulation ratio), recommendations and resolutions of authoritative international and European organizations (level of «shadow economy», decile ratio, ratio of total public debt to GDP, expenditures on science and education, crime), and estimating the coefficient of financing The needs of the national defense of the state and environmental costs are the result of the peculiarities of the practice and experience of the leading countries of the world.

A small number of suggested indicators is due to the law of the necessary diversity of Ashby, which defines the basic requirements for the ability of the management system to make choices [19]. Another important fact is that the growth of each individual indicator of $X_{i}$ must be linked to the growing state of state security. When there is an opposite trend for any indicator, it should be replaced by a conjugate.

\section{Step 5: Expert assessment of national security indicators.}

For each national security indicator $X_{i}$ specifies the linguistic variable $B_{i}$ («the level of the $\left.X_{i} »\right)$, which corresponds to the value of the following term sets:

- $B_{i 1}=$ extremely low level of $X_{i}$;

- $B_{i 2}=$ very low level of $X_{i}$;

- $B_{i 3}=$ low level of $X_{i}$;

- $B_{i 4}=$ average level of $X_{i}$;

- $B_{i 5}=$ high level of $X_{i}$;

- $B_{i 6}=$ very high level of $X_{i}$;

- $B_{i 7}=$ extremely high level of $X_{i}$.

Suppose each linguistic variable has a trapezoidal membership function, which is defined by a quadruple of numbers $\left(a_{1}, a_{2}, a_{3}, a_{4}\right)$, that is, the membership function of each term $B_{i j}$ has the form (1).

\begin{tabular}{|c|c|c|c|c|c|c|c|}
\hline \multirow{2}{*}{$\begin{array}{l}\text { Indi- } \\
\text { cators }\end{array}$} & \multicolumn{7}{|c|}{ Terms } \\
\hline & $B_{i 1}$ & $B_{i 2}$ & $B_{i 3}$ & $B_{i 4}$ & $B_{i 5}$ & $B_{i 6}$ & $B_{i 7}$ \\
\hline$X_{1}$ & $\begin{array}{ll}(0 ; \quad 0 ; & 0,1 ; \\
0,15) & \end{array}$ & $\begin{array}{l}(0,1 ; \quad 0,15 \\
0,25 ; 0,3)\end{array}$ & $\begin{array}{l}(0,25 ; \quad 0,3 ; \\
0,4 ; 0,45)\end{array}$ & $\begin{array}{l}(0,4 ; \quad 0,45 ; \\
0,55 ; 0,6)\end{array}$ & $\begin{array}{l}(0,55 ; \quad 0,6 ; \\
0,65 ; 0,75)\end{array}$ & $\begin{array}{l}(0,7 ; 0,75 ; \\
0,85 ; 0,9)\end{array}$ & $\begin{array}{l}0,85 ; \quad 0,9 ; \\
1,0 ; 1,0)\end{array}$ \\
\hline$X_{2}$ & $\begin{array}{lll}0 ; & 0 ; & 0 ; \\
0,005) & \end{array}$ & $\begin{array}{ll}0 ; & 0,005 ; \\
0,001 ; & 0,015)\end{array}$ & $\begin{array}{ll}0,001 ; & \\
0,015 ; & 0,02 ; \\
0,025) & \end{array}$ & $\begin{array}{l}0,02 ; 0,025 ; \\
0,03 ; 0,035)\end{array}$ & \begin{tabular}{|l}
0,$03 ;$ \\
0,$035 ; 0,04 ;$ \\
$0,045)$
\end{tabular} & \begin{tabular}{|l|}
0,$04 ;$ \\
0,$045 ; 0,05 ;$ \\
$0,055)$
\end{tabular} & $\begin{array}{l}0,05 ; \\
0,055 ; 0.08 ; \\
0,18)\end{array}$ \\
\hline$X_{3}$ & $\begin{array}{l}1 ; \quad 0,98 ; \\
0,97 ; 0,965)\end{array}$ & 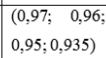 & $\begin{array}{l}(0,95 ; \quad 0,93 ; \\
0,92 ; 0,9)\end{array}$ & $\begin{array}{l}(0,92 ; 0,885 ; \\
0,865 ; 0,84)\end{array}$ & $\begin{array}{l}(0,865 ; 0,8 \\
0,75 ; 0,7)\end{array}$ & $\begin{array}{l}(0,75 ; \quad 0,6 ; \\
0,55 ; 0,4)\end{array}$ & $\begin{array}{ll}(0,55 ; & 0,2 ; \\
0 ; 0) & \end{array}$ \\
\hline$X_{4}$ & $\begin{array}{l}1 ; \quad 0,975 ; \\
0,9625 ; \\
0,95625)\end{array}$ & \begin{tabular}{|l|}
$(0,9625 ;$ \\
0,$95 ; 0,9375 ;$ \\
$0,93125)$
\end{tabular} & \begin{tabular}{|l|}
0,$9375 ;$ \\
0,$925 ;$ \\
0,$9125 ;$ \\
$0,90625)$
\end{tabular} & $\begin{array}{l}0,9125 ; 0,9 ; \\
0,8875 ; \\
0,875)\end{array}$ & \begin{tabular}{|l|}
$(0,8875 ;$ \\
0,$8375 ; 0,8 ;$ \\
$0,75)$
\end{tabular} & $\begin{array}{l}0,8 ; 0,625 ; \\
0,5 ; 0,375)\end{array}$ & \begin{tabular}{|l|}
0,$5 ;$ \\
0,$3125 ;$ \\
$0,1875 ; 0)$
\end{tabular} \\
\hline$X_{5}$ & $\begin{array}{lll}(1 ; 1 ; & 0,9 ; \\
0,85) & \end{array}$ & $\begin{array}{l}(0,9 ; \quad 0,85 ; \\
0,75 ; 0,7)\end{array}$ & $\begin{array}{l}(0,75 ; \quad 0,7 ; \\
0,6 ; 0,55)\end{array}$ & $\begin{array}{l}0,6 ; \quad 0,55 \\
0,45 ; 0,4)\end{array}$ & $\begin{array}{l}(0,45 ; \quad 0,4 ; \\
0,3 ; 0,25)\end{array}$ & $\begin{array}{l}(0,3 ; 0,25 ; \\
0,15 ; 0,1)\end{array}$ & $\begin{array}{l}0,15 ; \quad 0,1 ; \\
0 ; 0)\end{array}$ \\
\hline$X_{6}$ & $\begin{array}{l}\left(\begin{array}{lll}0 ; & 0 ; & 0,01 ; \\
0,015)\end{array}\right.\end{array}$ & $\begin{array}{l}0,01 ; 0,015 ; \\
0,025 ; 0,03)\end{array}$ & \begin{tabular}{|l}
0,$025 ; 0,03 ;$ \\
$0,4 ; 0,045)$
\end{tabular} & $\begin{array}{l}0,4 ; 0,045 ; \\
0,055 ; 0,6)\end{array}$ & \begin{tabular}{|l}
0,$055 ; 0,6 ;$ \\
0,$075 ;$ \\
$0,08)$
\end{tabular} & \begin{tabular}{|l|} 
\\
$(0,075 ;$ \\
0,$08 ; 0,085 ;$ \\
$0,9)$
\end{tabular} & $\begin{array}{l}(0,085 ; 0,9 ; \\
1,0 ; 1,0)\end{array}$ \\
\hline$X_{7}$ & $\begin{array}{l}(0 ; 0 ; 0,04 ; \\
0,06)\end{array}$ & $\begin{array}{l}(0,04 ; \quad 0,06 ; \\
0,07 ; 0,08)\end{array}$ & $\begin{array}{l}(0,07 ; \quad 0,08 ; \\
0,09 ; 0,1)\end{array}$ & $\begin{array}{l}(0,09 ; \quad 0,1 ; \\
0,15 ; 0,2)\end{array}$ & $\begin{array}{ll}(0,2 ; \quad 0,3 ; \\
0,35 ; 0,45)\end{array}$ & \begin{tabular}{|l}
$(0,35 ; 0,45 ;$ \\
$0,5 ; 0,6)$
\end{tabular} & $\begin{array}{l}0,5 ; \quad 0,6 ; \\
0,7 ; 0,8)\end{array}$ \\
\hline $\boldsymbol{X}_{8}$ & $\begin{array}{lll}(1 ; 1 ; & 0,6 ; \\
0,4) & \end{array}$ & $\begin{array}{l}0,55 ; \quad 0,4 ; \\
0,35 ; 0,3)\end{array}$ & $\begin{array}{l}(0,35 ; \quad 0,3 ; \\
0,25 ; 0,2)\end{array}$ & $\begin{array}{l}(0,25 ; \quad 0,2 ; \\
0,15 ; 0,1)\end{array}$ & \begin{tabular}{|l|}
$(0,15 ;$ \\
0,$125 ; 0,12 ;$ \\
$0,1)$
\end{tabular} & $\begin{array}{ll}(0,12 \quad 0,1 ; \\
0,09 ; 0,05)\end{array}$ & $\begin{array}{l}(0,09 ; 0,05 ; \\
0 ; 0)\end{array}$ \\
\hline
\end{tabular}

Fig. 3. Expert assessments of national security indicators 


\section{Step 6: Significance of indicators.}

The next step of the technique is the transition from the national security indicators $X=X_{1}, X_{2}, X_{3}, X_{4}, X_{5}, X_{6}, X_{7}, X_{8} \quad$ to $\quad$ statements about the state of state protection $G=$ $G_{1}, G_{2}, G_{3}, G_{4}, G_{5}, G_{6}, G_{7}$.

In order to establish the transition from the national security indicators $X_{i}$ to the linguistic variables $G_{i}$, each national security index must be compared with the degree of its contribution to the state of the state's security, that is, to establish for each indicator $X_{i}$ its weight $r_{i}$, which determines the contribution of the indicator to the state of security of the state. If the scales of the indicators are ordered, that is, $r_{1} \geq r_{2} \geq$ $\ldots \geq r_{n}$ and no other information on these values, then the weight is determined by the Fisher's rule [12]:

$$
r_{i}=\frac{2(n+1-i)}{n(n+1)}
$$

where $n$-number of indicators of national security; and $i$ - the number (rank) of the national security index in the order of its importance. In doing so, the condition of valuation is fulfilled:

$\sum_{i=1}^{n} r_{i}=1, i=1,2, \ldots, 8$.

Thus, (2) corresponds to the principle of the maximum entropy of the available information uncertainty of the research object. If the system of benefits is absent, then the indicators are equivalent:

$$
r_{i}=\frac{1}{n}
$$

For the indicators of our choice $X_{i}, i=1,2, \ldots, 8$ the formula (3) will be: $r_{i}=1 / 8$.

For the chosen system of scales, according to [18], the rule of transition from the values of the national security indicators to the weight terms of the linguistic variable $g$ has the form

$$
p_{k}=\sum_{i=1}^{8} r_{i} \mu_{k i}, k=1,2, \ldots, 7 .
$$

By calculating the weights of each term of the linguistic variable $G_{i}$, using formula (4) we obtain the value of the variable $g$ itself

$$
g=\sum_{i=1}^{7} p_{k} \overline{g_{k}},
$$

where $\overline{g_{k}}$ is the middle of the space that is the bearer of the term $G_{k}\left(a_{k 1}, a_{k 8}\right]$.

The transition from the indicators of national security to linguistic assessments of state security is shown in Fig. 2.

For a better understanding of the methodology for assessing the state of the state's security in terms of the theory of fuzzy sets, we apply the proposed algorithm to the indicators of national security of Ukraine for the period 2010-2016. Let's give them a brief description.

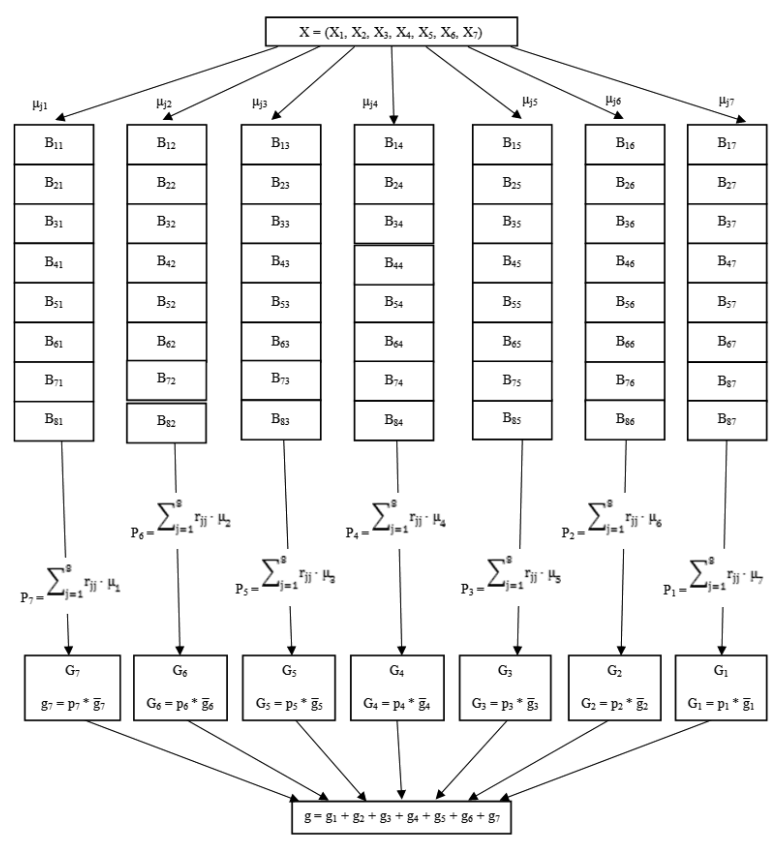

Fig. 4. The scheme of transition from the indicators of national security to statements about the state of state security

$\boldsymbol{X}_{1}$ : Perhaps the greatest problem of the national security of our country is the demographic component: in Ukraine, the process of depopulation of the population continues, which is one of the greatest threats to national security. In our opinion, the indicator of the threat to the demographic security of the state can be considered the coefficient of depopulation (coefficient of vitality Pokrovsky). It shows the size of the population decline in the country, in which the birth rate is not sufficient to compensate for even a very low mortality rate. On the basis of the absolute number of births and deaths, calculate the depopulation rate

$$
K_{v}=\frac{N}{M} * 100
$$

where $K_{v}$ - coefficient of vitality (Pokrovsky), $N-$ number of births per period (year), $M-$ the number of deaths for the same period. The depopulation rate shows the number of births per 100 deaths.

$\boldsymbol{X}_{\mathbf{2}}$ : Each indicator characterizing the sphere of national defense of the state should reflect not only the real economic situation of the state, but also the full satisfaction of defense needs, the distribution of relevant expenditures in the key areas: for the maintenance of the Armed Forces; on their preparation; on the development of weapons, military equipment and infrastructure. Such an indicator may be the level of expenditures on national defense as a percentage of GDP, which is an important indicator of the state's defense capability. It is believed that the financing factor for the needs of national defense should be at least $2 \%$ of GDP.

$\boldsymbol{X}_{\mathbf{3}}$ : the problem of «shadowing» the economy is relevant to all countries of the world. However, the main differences in one or another country are its volume, factors, the state of social and legal control, the 
regulatory activity of the state, the implementation of state strategies, programs to combat shadow economic activity, indicators of living standards of the population. It is believed that the scale of the shadow economy in the amount of $5-10 \%$ of GDP does not have a significant impact on socio-economic processes in society, do not cause significant violations in the economy and are considered permissible. With the size of the shadow sector over $30 \%$ of GDP comes a critical mass, the excess of which indicates the functioning of the country's reproduction system of shadow economic relations. Expansion of the shadow economy to the specified sizes also leads to the imbalance of certain spheres of the economy, the deepening of uncontrolledness and the criminalization of society.

$\boldsymbol{X}_{4}$ : the development of market relations in Ukraine caused a significant stratification of society in terms of material well-being, which is the result of a large inequality in the distribution of income of the population. The decile factor (the income differentiation index, that is, the income difference of $10 \%$ of the richest families and $10 \%$ of the poorest) should not exceed the 10-fold rate. The large number of people living below the poverty line, as well as the substantial differentiation of incomes, generate not only economic but also many negative social consequences, the main of which is the violation of the democratic principles of the existence of a market economy and human rights to a decent life.

$\boldsymbol{X}_{\mathbf{5}}$ : debt security indicators are the most objective instrument for determining the impact of public debt on the financial and economic position of the state. At the same time, the ratio of the total public debt to GDP should be no more than $55 \%$. The consequences of an increase in public debt are: high inflation growth, higher prices than wage payments, dependence of the country on creditors and increase Ukraine's obligations to fulfill their conditions, devaluation of the national currency, and consequently the deterioration of the quality of life of the population, reduction of their real incomes, a significant increase in energy prices. This makes it impossible to ensure the social and economic stability of the state and the balanced development of society.

$\boldsymbol{X}_{\mathbf{6}}$ : Ukraine, which wants to achieve the modern technological level, must implement a focused technological policy and prevent a backlog in technological development, which will provide it with sustained economic development and national security. In doing so, it is necessary to take into account both the existing technological level of production in all branches of the economy, and the technological structure of each of them. To ensure systematic measures aimed at solving the problems of national security in the scientific and technological sphere, support of national critical technologies, implementation of the state strategy of scientific and technological development of Ukraine and creation of real conditions for the transition of the economy to an innovative model of development based on its own scientific potential, the limit value of financing Ukrainian science should not be less than $3 \%$ of GDP.

$\boldsymbol{X}_{\mathbf{7}}$ : the indicator of taking into account longterm environmental priorities is the share of GDP allocated to the implementation of environmental protection projects and programs, i.e. total environmental costs, which should not be less than $8-10 \%$ of GDP, and for countries with a tense ecological situation (which, incidentally, Ukraine also applies) - even higher, up to $12-15 \%$.

$\boldsymbol{X}_{\mathbf{8}}$ : crime is a relatively massive, historically variable, social and criminal phenomenon, which is an integral set of all crimes committed in a certain territory for the appropriate period of time. Despite all the difficulties, the comparative and statistical study of crime allows us to identify the main trends, the dynamics of this crime in the world, its structure and peculiarities of regional manifestations. In world practice, it is recognized that the excess of the 5 to 6 crimes per 100 people over a year may lead to the criminalization of public relations in the state.

Taking into account that the research results for the whole given period occupy a lot of space, one year is enough to illuminate the algorithm of calculations (2010). Levels of indices (keystone numbers) are taken from Fig. 3, the value function of the membership of each fuzzy number is calculated using formula (1).

\begin{tabular}{|l|l|l|}
\hline \multicolumn{1}{|c|}{ Indicator } & \multicolumn{1}{|c|}{ Trapezoidal numbers } & \multicolumn{1}{c|}{ The value of membership function } \\
\hline \multirow{3}{*}{$\mathrm{X} 1=0,712833$} & $\mathrm{~B}_{15}(0,55 ; 0,6 ; 0,65 ; 0,75)$ & $\mu_{51}=0,371670009$ \\
\cline { 2 - 3 } & $\mathrm{B}_{16}(0,7 ; 0,75 ; 0,85 ; 0,9)$ & $\mu_{61}=0,256659983$ \\
\hline \multirow{3}{*}{$\mathrm{X} 2=0,0115$} & $\mathrm{~B}_{22}(0 ; 0,005 ; 0,001 ; 0,015)$ & $\mu_{22}=0,25$ \\
\cline { 2 - 4 } & $\mathrm{B}_{23}(0,01 ; 0,015 ; 0,02 ; 0,025)$ & $\mu_{32}=0,75$ \\
\hline $\mathrm{X} 3=0,041$ & $\mathrm{~B}_{37}(0,55 ; 0,2 ; 0 ; 0)$ & $\mu_{73}=1$ \\
\hline $\mathrm{X} 4=0,347$ & $\mathrm{~B}_{47}(0,5 ; 0,3125 ; 0,1875 ; 0)$ & $\mu_{74}=0,816$ \\
\hline $\mathrm{X} 5=0,0082$ & $\mathrm{~B}_{57}(0,15 ; 0,1 ; 0 ; 0)$ & $\mu_{75}=1$ \\
\hline \multirow{2}{*}{$\mathrm{X} 6=0,0121$} & $\mathrm{~B}_{61}(0 ; 0 ; 0,01 ; 0,015)$ & $\mu_{16}=0,58$ \\
\cline { 2 - 4 } & $\mathrm{B}_{62}(0,01 ; 0,015 ; 0,025 ; 0,03)$ & $\mu_{26}=0,42$ \\
\hline $\mathrm{X} 7=0,0104206$ & $\mathrm{~B}_{71}(0 ; 0 ; 0,04 ; 0,06)$ & $\mu_{17}=1$ \\
\hline $\mathrm{X} 8=0,38$ & $\mathrm{~B}_{82}(0,55 ; 0,4 ; 0,35 ; 0,3)$ & $\mu_{28}=1$ \\
\hline
\end{tabular}

Fig. 5. Primary processing of indicators of national security

Calculating the value of the membership function of the linguistic variable in 2010 in accordance with the scheme depicted in Fig. 4.

\section{Step 7: Assessing membership function.}

Using the results of calculations in Fig. 6, we determine the value of the membership function $\mu_{k}(g)$ for $g$ $=0,46$ :

$$
\mu_{4}= \begin{cases}1-20(0,45-g) & \text { if } 0,4<g \leq 0,45 \\ 1 & \text { if } 0,45<g \leq 0,55 \\ 20(0,6-g) & \text { if } 0,55<g \leq 0,6\end{cases}
$$




\begin{tabular}{|l|l|l|l|}
\hline \multicolumn{1}{|c|}{$\begin{array}{c}\text { Weight coefficient of term } \boldsymbol{p}_{\boldsymbol{k}} \\
\text { of linguistic } \boldsymbol{g}\end{array}$} & $\begin{array}{c}\text { The set of the } \\
\text { k-th term carrier of } \\
\text { the linguistic } \\
\text { variable } \boldsymbol{g}\end{array}$ & $\begin{array}{c}\text { The average } \\
\text { value of the } \\
\text { interval } \\
\boldsymbol{G}_{\boldsymbol{k}}, \boldsymbol{g}_{\boldsymbol{k}}\end{array}$ & $\boldsymbol{g}_{\boldsymbol{k}}=\boldsymbol{p}_{\boldsymbol{k}} \cdot \overline{\boldsymbol{g}_{\boldsymbol{k}}}$ \\
\hline$p_{7}=\sum_{i=1}^{8} r \mu_{7 i}=\frac{1}{8} \cdot\left(\mu_{73}+\mu_{74}+\mu_{75}\right) \approx 0,352$ & $G_{7} \in[0 ; 0,15]$ & 0,075 & 0,0264 \\
\hline$p_{6}=\sum_{i=1}^{8} r \mu_{6 i}=\frac{1}{8} \cdot \mu_{61}=\frac{1}{8} \cdot 0,257 \approx 0,032$ & $G_{6} \in[0,1 ; 0,3]$ & 0,2 & 0,0064165 \\
\hline$p_{5}=\sum_{i=1}^{8} r \mu_{5 i}=\frac{1}{8} \cdot \mu_{51}=\frac{1}{8} \cdot 0,372 \approx 0,047$ & $G_{5} \in[0,25 ; 0,45]$ & 0,35 & 0,016260563 \\
\hline$p_{4}=\sum_{i=1}^{8} r \mu_{4 i}=0$ & $G_{4} \in[0,4 ; 0,6]$ & 0,5 & 0 \\
\hline$p_{3}=\sum_{i=1}^{8} r \mu_{3 i}=\frac{1}{8} \cdot \mu_{32}=\frac{1}{8} \cdot 0,75 \approx 0,094$ & $G_{3} \in[0,55 ; 0,75]$ & 0,65 & 0,0609375 \\
\hline$p_{2}=\sum_{i=1}^{8} r \mu_{2 i}=\frac{1}{8} \cdot\left(\mu_{22}+\mu_{26}+\mu_{28}\right) \approx 0,21$ & $G_{2} \in[0,7 ; 0,9]$ & 0,8 & 0,167 \\
\hline$p_{1}=\sum_{i=1}^{8} r \mu_{1 i}=\frac{1}{8} \cdot\left(\mu_{16}+\mu_{17}\right) \approx 0,198$ & $G_{1} \in[0,85 ; 1]$ & 0,925 & 0,1826875 \\
\hline$g=\sum_{k=1}^{7} g_{k}=0,46$ & &
\end{tabular}

Fig. 6. Value of the membership function of the linguistic variable $G=$ «state of the state security»

$$
\mu_{4}(0,46)=1, \mu_{k}=0, k=1,2,3,5,6,7,8 .
$$

Description of the state of the state security for 2010: «the average state of state security». At the moment, the theory of fuzzy sets is fundamentally new technology for the constructive use of knowledge in the theory of national security. Due to the simulation of situations arising from the interaction of interests and values of actors of protection and threats, the source of which are complex systems and the environment surrounding them, it is possible to achieve significantly better quality control of these systems. First of all, it concerns the decision-making in their interests, based on an assessment of the trend of the situation that has objectively developed at the present time. The functions of the use of the linguistic variable $G=$ «the average state of state security» during 2010-2016 are given in Fig 7.

\begin{tabular}{|l|l|l|l|}
\hline Year & $\begin{array}{l}\text { Value of } \\
\text { membership } \\
\text { function }\end{array}$ & Level & $\begin{array}{l}\text { Level } \\
\text { value }\end{array}$ \\
\hline 2010 & 0,459702062 & 4 & average \\
\hline 2011 & 0,454983917 & 4 & average \\
\hline 2012 & 0,450532143 & 4 & average \\
\hline 2013 & 0,457548214 & 4 & average \\
\hline 2014 & 0,457519076 & 4 & average \\
\hline 2015 & 0,456729069 & 4 & average \\
\hline 2016 & 0,474868195 & 4 & average \\
\hline
\end{tabular}

Fig. 7. Functions of the linguistic variable $G=$ «state of the state security»

In the history of Ukraine, the year of 2014 became decisive, marked by the Revolution of Dignity, the annexation of the Crimea, as well as the anti-terrorist operation in connection with the unpublished war in the East of Ukraine. Figure 5 shows a graphic repre- sentation of the results obtained (Fig.6, Fig.7). It well reflects the course of these events: all calculated values of the function of the linguistic variable $G=$ «state of state security» belong to the fourth level - the average state of security, a decline in state security of the state before the aggression of the $\mathrm{RF}$, and then gradually increase it.

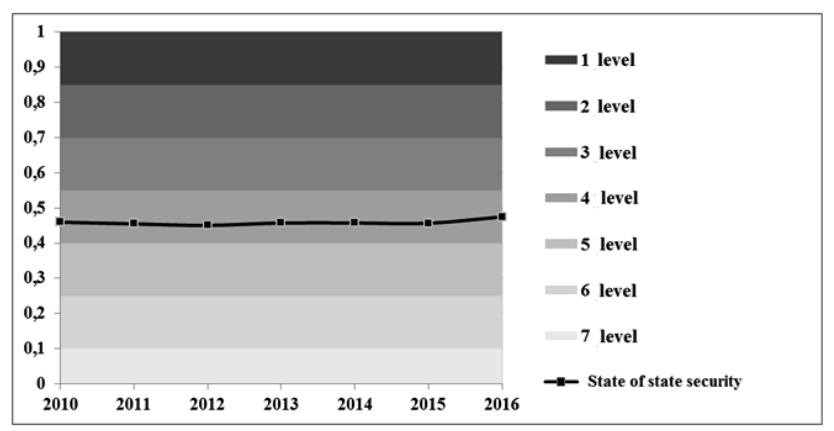

Fig. 8. Trends in the development of the situation in the national security of Ukraine during 2010-2016.

It is obvious that the use of fuzzy sets technology in the theory of national security enables decision-makers to act ahead and not to bring potentially dangerous situations to conflicts or catastrophic states, and if they arise, to make rational decisions in their interests.

\section{Conclusions.}

An analysis of the methods used to assess the level of national security available in the national and international literature shows that due to a number of shortcomings, they inadequately reflect the state of security of its main objects of protection. In connection with this, there is a need to improve the methodology for assessing the level of national security. One of the ways to improve the effectiveness of assessing the level of national security is the use of the theory of fuzzy sets and the development on their basis of fundamentally new mechanisms for assessing the level of national security. The approach outlined in the article allows individuals who make decisions in the system of ensuring national security not only to formalize their fuzzy representations, but also to transform expert assessments into a quantitative assessment of the state of security of objects of protection.

The method proposed in this article is a substantially modified version of the analysis of financial risk. In its general form, it can be considered as an in-depth, selective study of the security status of any object of the security system. Therefore, this technique can be used in such an important area of national security as cybernetic security. In the perspective of such a study, first of all, there should be a justification of the system of indicators of cybersecurity.

Thus, the method of assessing the level of national security, based on the use of the theory of fuzzy sets, allows simultaneous use of different types of information: deterministic, statistical and linguistic, which is difficult to implement using other methods. As a result, ODA receives data on the level of protection of the main 
objects of national security, its linguistic assessment in the form of a statement «high level-low». This approach can also be useful for monitoring the dangerous processes taking place in the field of national security.

\section{References}

[1] P. Borishpolc K. Metody politicheskix issledovanij. - M. : Aspekt Press, 2005.

[2] V. Popova O. Politicheskij analiz i prognozirovanie. - M. : Aspekt Press, 2011.

[3] B. Kachinskij A. Indikatori nacionalnoi bezpeki: viznachennya ta zastosuvannya. - K. : NISD, 2013.

[4] V. Vozzhennikov A. Nacionalnaya bezopasnost: teoriya, praktika, strategiya. - M. : NPO «Modul», 2000.

[5] I. Yarochkin V. Sekyuritilogiya - nauka o bezopasnosti zhiznedeyatelnosti. - M. : Os, 2000.

[6] A. Leskov M. Gomeostaticheskie processy i teoriya bezopasnosti // Bezopasnost. - 1994. - № 4. C. 66-75.

[7] D. Mogilevskij V. Metodologiya sistem: verbalnyj podxod. - M. : Ekonomika, 1999.

[8] V. Prangishvili I. Sistemnyj podxod i obshhesistemnye zakonomernomernosti. M. : SIN-TEG, 2000.

[9] A. Proxozheva A. Obshhaya teoriya nacionalnoj bezopasnosti. - M. : Izd-vo RAGS, 2002.

[10] V. Belevceva V. Administrativno-pravovye rezhimy obespecheniya stabilnosti gosudarstva // Uchenye zapiski Tavricheskogo nacionalnogo universiteta imeni V. I. Vernadskogo. Seriya «Yuridicheskie nauki». - № T. 25 (64), № 2. - C. 244-251.
[11] Bityak Y. P. Garashhuk V. M. Dyachenk O. V. et al. Системный анализ инфраструктуры как элемент народного хозяйства. - K. : Yurinkom Inter, 2005.

[12] Zgurovskij M. Z. Zajchenko Y. P. Kompleksnyj analiz riska bankrotstva korporacij v usloviyax neopredelennosti 1 // Sistemni doslidzhennya ta informacijni texnologii. - 2012. - № 1. - C. 113128.

[13] O. Nedosekin A. Primenenie teorii nechetkix mnozhestv k zadacham upravleniya finansami // Audit i finansovyj analiz. — 2012. — № №1 (17). C. $15-17$.

[14] L. Zade. Ponyatie lingvisticheskoj peremennoj i ego primenenie $\mathrm{k}$ prinyatiyu priblizhennyx reshenij. M. : Mir, 1976.

[15] Zgurovskij M. Z. Zajchenko Y. P. Osnovy vychislitelnogo intellekta. - K. : Naukova dumka, 2013.

[16] A. Kofman. Vvedenie v teoriyu nechetkix mnozhestv. - M. : Radio i svyaz, 1982.

[17] A. Miller G. The magical number seven plus or minus two: Some limits on our capacity for processing information // Psychological Review. - 1956. no. 63. - P. 81-97.

[18] Konysheva L. K. Nazarov D. M. Osnovy teorii nechetkix mnozhestv. - SPb. : Piter, 2011.

[19] Volkova V. N. Denisov A. A. Teoriya sistem: uchebnoe posobie. - M. : Vysshaya shkola, 2006. 